Arq. Bras. Med. Vet. Zootec., v.68, n.4, p.845-852, 2016

\title{
Physical and morphological characteristics of the first three jets of Pêga jackasses sperm-rich fraction
}

\author{
[Características físicas e morfológicas dos três primeiros jatos da fração rica do \\ ejaculado de jumentos da raça Pêga] \\ L.E. Carvalho ${ }^{1}$, J.M. Silva Filho ${ }^{2 *}$, M.S. Palhares ${ }^{2}$, A.L.R. Sales ${ }^{1}$, A.T. Gonczarowska ${ }^{1}$, \\ H.N. Oliveira ${ }^{3}$, M. Resende ${ }^{4}$, R. Rossi ${ }^{1}$ \\ ${ }^{1}$ Aluna de pós-graduação - Universidade Federal de Minas Gerais - Belo Horizonte, MG \\ ${ }^{2}$ Escola de Veterinária - Universidade Federal de Minas Gerais - Belo Horizonte, MG \\ ${ }^{3}$ Escola de Veterinária - UNESP - Jaboticabal, SP \\ ${ }^{4}$ Médico veterinário autônomo - Belo Horizonte, MG
}

\begin{abstract}
The first three jets of the sperm-rich fraction of Pêga jackasses were collected and assessed separately. Five fertile Pêga jackasses were used as semen donors and underwent fractionated semen collection, using an open model artificial vagina. The first three jets of the semen were collected separately and assessed for volume, sperm motility, vigor, concentration $/ \mathrm{mL}$ of semen, and sperm morphology. These characteristics were compared between first, second and third jets and between jackasses. It was observed that the jet volume differed $(\mathrm{P}<0.05)$ between jackasses, although it was similar $(\mathrm{P}>0.05)$ between first, second and third jets. Sperm motility did not differ $(\mathrm{P}>0.05)$ between jets and jackasses. Vigor was similar $(\mathrm{P}>0.05)$ between jets of the same jackass, and only the first jet differed $(\mathrm{P}<0.05)$ between jackasses. The first, second and third jets of the sperm-rich fraction had decreased sperm concentrations $(\mathrm{P}<0.05)$ of 955.56, 725.56 and 280.56x 106 sperm $/ \mathrm{mL}$ of semen, respectively. Sperm morphology differed between the first three jets only for the incidence of mid-piece defect, higher in the third one (4.26\%), compared to the first $(3.36 \%)$ and second $(3.38 \%)$ ones. When comparing the morphological characteristics of the sperm-rich fraction between five jackasses, regardless of the jet, there were differences in the percentage of normal sperm, proximal cytoplasmic droplet, mid-piece and head defects.
\end{abstract}

Keywords: jackass, fractionated ejaculate, jets, sperm-rich fraction

\section{RESUMO}

Objetivou-se, no presente experimento, caracterizar os três primeiros jatos da fração rica do ejaculado de jumentos da raça Pêga. Para tal, cinco jumentos foram submetidos à coleta fracionada do sêmen, utilizando-se vagina artificial modelo aberta. Os três primeiros jatos da fração rica do ejaculado foram coletados separadamente e avaliados quanto ao volume, à motilidade e ao vigor espermáticos, à concentração espermática/mL de sêmen e à morfologia espermática. Comparações foram realizadas entre jatos e entre jumentos. Observou-se que o volume do jato diferiu $(P<0,05)$ entre os jumentos, embora fosse similar $(P>0,05)$ entre os jatos. A motilidade espermática não diferiu $(P>0,05)$ entre jatos nem entre jumentos. $O$ vigor espermático foi similar $(P>0,05)$ entre os jatos de um mesmo jumento, e apenas o vigor do jato 1 diferiu $(P<0,05)$ entre os jumentos. Independentemente do jumento, a fração rica do ejaculado foi composta por três jatos apresentando concentrações espermáticas decrescentes $(P<0,05)$, com 955,56; 725,56 e 280,56 x $10^{6}$ espermatozoides $/ \mathrm{mL}$ de sêmen. A morfologia espermática diferiu entre os três jatos avaliados apenas para a incidência de defeitos de peça intermediária, sendo maior no jato três (4,26\%), em relação aos jatos um $(3,36 \%)$ e dois (3,38\%). Comparando-se as características morfológicas do sêmen entre os cinco jumentos avaliados, independentemente do jato, observaram-se diferenças entre os reprodutores quanto ao percentual de espermatozoides normais, com gota citoplasmática proximal, com defeitos de peça intermediária e de cabeça.

Palavras-chave: jumento, coleta fracionada, jatos, fração rica

Recebido em 7 de agosto de 2014

Aceito em 11 de fevereiro de 2016

* Autor para correspondência (corresponding author)

E-mail: silvafilhojm@gmail.com 


\section{INTRODUCTION}

There are few studies in literature assessing physical and morphological semen characteristics from the sperm-rich fraction of different jackasses.

In equidae species, ejaculation occurs in jets. Equine ejaculate consists of 5 to 10 jets (Tischner et al., 1974), while in jackass ejaculate, Mann et al. (1963) reported the occurrence of five jets.

In general, the ejaculate is divided into three fractions: pre-sperm, sperm-rich and post-sperm fractions; they originate from bulb-urethral glands, deferens ducts and vesicular glands, respectively (Mann et al., 1963; Magistrini et al., 2000). Thus, the composition of seminal plasma varies among fractions of the semen. Tischner et al. (1974) reported that in stallions the first three jets of sperm-rich fraction could contain up to $80 \%$ of the total sperm, while Mello (1998) observed that in jackasses up to $94 \%$ of the total sperm was in the first two jets of the ejaculate.

Mann et al. (1963) characterized jackass semen fractions. The pre-sperm fraction consisted of a transparent fluid, with a volume of $2.8 \mathrm{~mL}$, with low sperm, ergothioneine and citric acid concentrations, considerable amounts of lactic acid $(12 \mathrm{mg} / \mathrm{dL})$, and high sodium chloride concentration $(850 \mathrm{mg} \mathrm{NaCl} / \mathrm{dl})$. The sperm-rich fraction was composed by three jets, with the same characteristics: yellowish aspect, high sperm and ergothioneine concentration, and lactic acid concentration similar to the pre-sperm fraction, but with lower amounts of sodium chloride $(744 \mathrm{mg} \mathrm{NaCl} / \mathrm{dl})$. The low citric acid concentration, derived from the vesicular glands, suggests the absence of involvement of this gland in the composition of the rich-sperm fraction. Finally, the post-sperm fraction had low sperm concentration, high lactic acid $(89 \mathrm{mg} / \mathrm{mL})$ and citric acid concentrations $(21.5 \mathrm{mg} / \mathrm{dl})$ and "gelatinous" transparent appearance, characteristic of vesicular secretion.

Several studies demonstrated deleterious effects of the presence of seminal plasma during storage of stallion and jackass semen (Varner et al., 1987; Jasko et al., 1991; Carver and Ball, 2002; Serres et al., 2002; Love et al., 2005; Moore et al., 2005; Miró et al., 2009), which effects are minimized by semen dilution. However, to achieve adequate dilution rates, minimum initial concentration is required, and often centrifugation of the total ejaculate is necessary. In this sense, the use of the sperm-rich fraction appears as an alternative due to its high concentration. After the study of Mann et al. (1963) and Mello (1998), further studies about the sperm-rich fraction of jackass semen were not performed. The aim of this study was to evaluate, separately, the first three jets of the sperm-rich fraction, since there is no similar study for Pêga Jackasses.

\section{MATERIAL AND METHODS}

The experiment was conducted in Lagoa Dourada, Minas Gerais, Brazil, from September 2010 to February 2011.

Five Pêga jackasses, aged between 5 and 17 years, were used as semen donors. Their fertility was proven due to good pregnancy rates checked previously. An open model artificial vagina (Figure 1) adapted from Tischner et al. (1974) was used to collect the first three jets of the ejaculate separately. This artificial vagina consisted of a thick rubber cylinder with $28 \mathrm{~cm}$ in length and $14 \mathrm{~cm}$ in diameter with a metal valve on one side. To collect the first three semen jets, three plastic flasks of $14 \mathrm{~cm}$ in diameter and capacity of $2.0 \mathrm{~L}$ were used. Sterile and disposable plastic bags with $25 \mathrm{~cm}$ in width and $35 \mathrm{~cm}$ in length were placed inside them (Figure 2). The semen collections were performed 2 to 3 times per week, using a dummy (Figure 3). A total of 18 sperm-rich fractions, each one composed by the first three jets, were evaluated.

The three jets of the sperm-rich fraction were collected in three different flasks identified by numbers 1, 2 and 3 corresponding to the first, second and third jets, respectively. One person was responsible for carrying and using the artificial vagina properly, and another was responsible for semen collection and carrying flasks 1 and 2 on the one hand, and flask 3 on the other hand. At the moment of ejaculation, the flasks were placed near the open end of the artificial vagina and the jets were collected in separate flasks (Figure 4). After collection, the flasks were sent to the laboratory. The plastic bags containing the semen were placed in a water bath at $37^{\circ} \mathrm{C}$. The semen was submitted to 
physical assessment (motility and vigor) using optical microscopes. The volume of each jet was measured using graduated glass tubes. To assess sperm concentration, a semen aliquot of $20 \mu \mathrm{L}$ was dissolved into $8 \mathrm{~mL}$ of buffered-formol saline solution (1:400) and the number of sperm $/ \mathrm{mL}$ was determined after counting spermatozoa in a haemocytometer (Neubauer chamber). Samples for morphology were taken from fresh semen and placed in ependorffs containing buffered-formol saline solution and subsequently evaluated in a phase-contrast microscopy. To determine the percentage of sperm defects, 200 cells in each sample were evaluated.

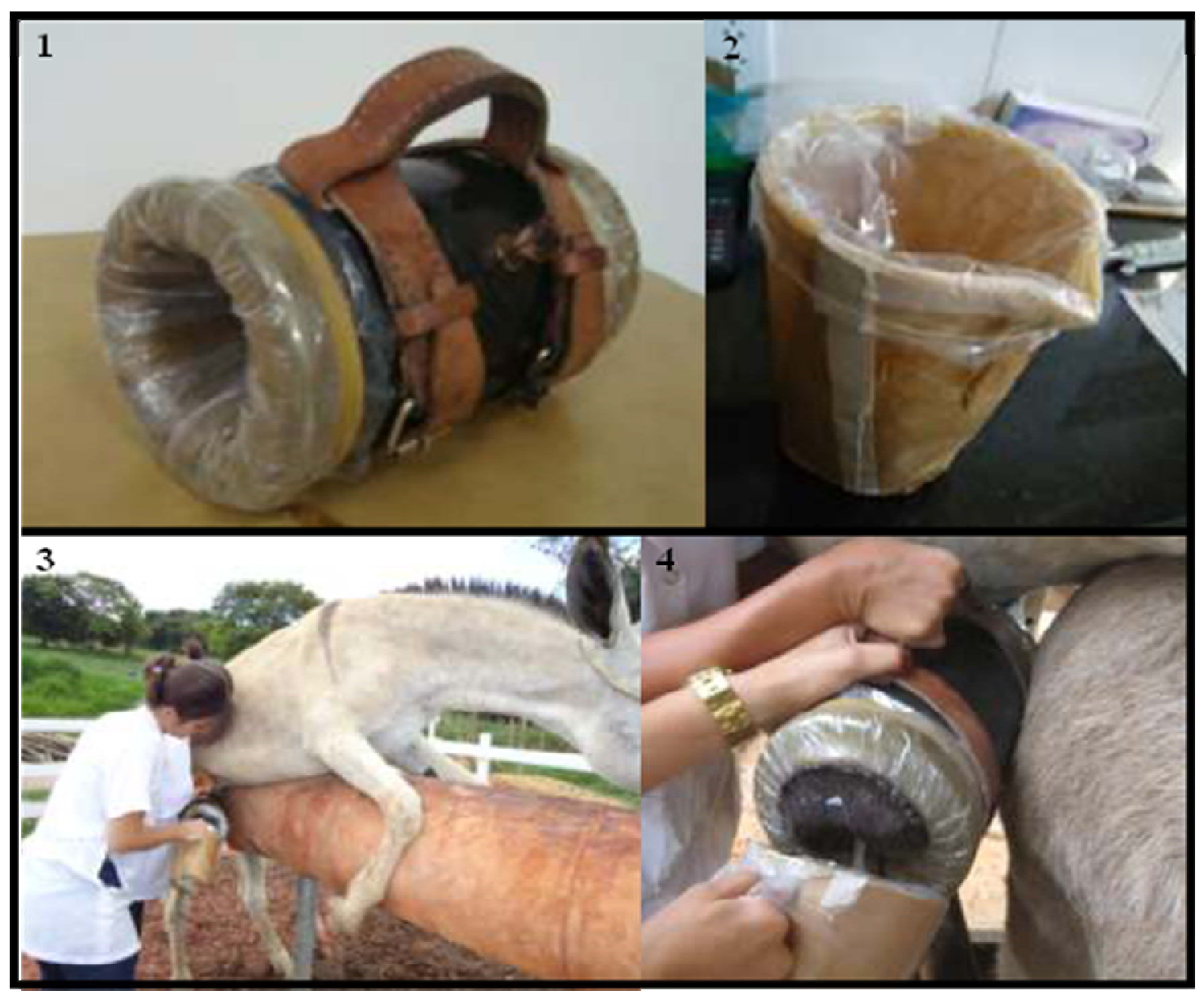

Figure 1. Open model artificial vagina. Figure 2. Flask used to collect jets 1, 2 and 3. Figure 3. Semen collection in dummy. Figure 4. Jet collected in a plastic flask.

Statistical analysis was processed using the Statistical Analysis System (Statistical, 1999) version 5, with significance level of $95 \%$ $(\mathrm{P}<0.05)$ and using the General Linear Models (GLM) for the analysis of variables. The values were expressed as mean \pm standard error. For evaluating the semen characteristics, the statistical model used included the effect of the jackass and the jets separately, as well as jet and jackass interaction.
The percentage values were transformed into arcsine $\sqrt{ } \%$ before the analysis. Quantitative variables were analyzed using the GLM procedure. For comparison of two means, the Student " $t$ " test was used, and to compare three or more means, the Student-Newman-Keuls (SNK) test was used. For sperm vigor, a nonparametric statistical analysis was used; the Kruskal-Wallis test was used when comparing more than two means, and the Wilcoxon test for comparison of two means. 


\section{RESULTS AND DISCUSSION}

The sperm characteristics evaluated, according to jackass and jet, are shown in Table 1.

Semen color and appearance were assessed and jets 1, 2 and 3 presented milky white color and showed no difference for these parameters. Semen volume $(\mathrm{mL})$, considering jet and jackass as sources of variation, was similar $(\mathrm{P}>0.05)$ between jets of the same jackass, but different $(\mathrm{P}<0.05)$ between jackasses. There was interaction between jet and jackass for this variable. For jackasses 1, 2 and 3, semen volume was similar $(\mathrm{P}<0.05)$ between jets and jackasses. However, the second jet from jackass 4 had more $(\mathrm{P}<0.05)$ volume compared to the first and second jets of jackass 5 . Also in this respect, the first jet of jackass 2 differed $(\mathrm{P}<0.05)$ from the second jet of jackass 5. Sperm motility was similar ( $\mathrm{P}>0.05)$ between jets and jackasses, and ranged from 75.0 to $87.5 \%$ for the first jet, 80 to $85 \%$ for the second jet, and 62.5 to $81.25 \%$ for the third jet. Spermatic vigor did not differ $(\mathrm{P}>0.05)$ between jets for the same jackass. However, considering only the first jet of the sperm-rich fraction, differences were observed between jackasses. Thus, sperm from the first jet of jackasses 1, 2 and 4 showed higher vigor $(\mathrm{P}<0.05)$ compared to the same jet from jackass 5. Jackass 3 had similar vigor $(\mathrm{P}>0.05)$ as the other jackasses (Table 1).

Since sperm concentration was similar between jets and jackasses (Table 1), it was possible to group the data to compare sperm concentration between jets, regardless of the jackass, which is shown in Table 2.

Table 1. Sperm characteristics of the first three jets from the sperm-rich fraction of Pêga jackasses

\begin{tabular}{|c|c|c|c|c|c|}
\hline \multirow[b]{2}{*}{ Jackass } & \multirow[b]{2}{*}{ Jet } & \multicolumn{4}{|c|}{ Sperm Morphology } \\
\hline & & $\begin{array}{l}\text { Volume } \\
\text { (mL) }\end{array}$ & $\begin{array}{c}\mathrm{N}^{0} \text { cells } \\
\left(\mathrm{x} 10^{6} \mathrm{sptz} / \mathrm{mL}\right)\end{array}$ & $\begin{array}{l}\text { Motility } \\
(0-100 \%)\end{array}$ & $\begin{array}{l}\text { Vigor } \\
(0-5)\end{array}$ \\
\hline \multirow{3}{*}{1} & 1 & $7.75 \pm 1.91^{\mathrm{ABC}}$ & $1115.00 \pm 124.21$ & $85.00 \pm 6.10$ & $5.00 \pm 0.29^{\mathrm{A}}$ \\
\hline & 2 & $4.13 \pm 1.91^{\mathrm{ABC}}$ & $907.50 \pm 124.21$ & $85.00 \pm 6.10$ & $4.88 \pm 0.29$ \\
\hline & $3 *$ & $6.13 \pm 1.91^{\mathrm{ABC}}$ & $210.00 \pm 124.21$ & $62.50 \pm 6.10$ & $3.63 \pm 0.29$ \\
\hline \multirow{3}{*}{2} & 1 & $13.75 \pm 1.91^{\mathrm{AB}}$ & $1105.00 \pm 124.21$ & $85.00 \pm 6.10$ & $5.00 \pm 0.29^{\mathrm{A}}$ \\
\hline & 2 & $7.00 \pm 2.20^{\mathrm{ABC}}$ & $575.00 \pm 124.21$ & $83.75 \pm 6.10$ & $4.88 \pm 0.29$ \\
\hline & 3 & $5.50 \pm 1.91^{\mathrm{ABC}}$ & $177.50 \pm 124.21$ & $80.00 \pm 6.10$ & $4.63 \pm 0.29$ \\
\hline \multirow{3}{*}{3} & 1 & $3.60 \pm 2.70^{\mathrm{ABC}}$ & $933.33 \pm 143.42$ & $83.33 \pm 7.04$ & $4.50 \pm 0.33^{\mathrm{AB}}$ \\
\hline & 2 & $3.75 \pm 2.70^{\mathrm{ABC}}$ & $830.00 \pm 143.42$ & $80.00 \pm 7.04$ & $4.50 \pm 0.33$ \\
\hline & 3 & $4.00 \pm 2.70^{\mathrm{ABC}}$ & $400.00 \pm 143.42$ & $78.33 \pm 7.04$ & $4.33 \pm 0.33$ \\
\hline \multirow{3}{*}{4} & 1 & $4.88 \pm 1.91^{\mathrm{ABC}}$ & $1020.00 \pm 124.21$ & $87.50 \pm 6.10$ & $5.00 \pm 0.29^{\mathrm{A}}$ \\
\hline & 2 & $14.50 \pm 1.91^{\mathrm{A}}$ & $745.00 \pm 124.21$ & $83.75 \pm 6.10$ & $5.00 \pm 0.29$ \\
\hline & 3 & $7.63 \pm 1.91^{\mathrm{ABC}}$ & $370.00 \pm 124.21$ & $81.25 \pm 6.10$ & $4.88 \pm 0.29$ \\
\hline \multirow{3}{*}{5} & 1 & $2.55 \pm 2.70^{\mathrm{BC}}$ & $480.00 \pm 143.42$ & $75.00 \pm 7.04$ & $4.17 \pm 0.33^{\mathrm{B}}$ \\
\hline & 2 & $1.15 \pm 2.70^{\mathrm{C}}$ & $553.33 \pm 143.42$ & $80.00 \pm 7.04$ & $4.33 \pm 0.33$ \\
\hline & 3 & $3.80 \pm 2.70^{\mathrm{ABC}}$ & $273.33 \pm 143.42$ & $73.33 \pm 7.04$ & $4.00 \pm 0.33$ \\
\hline
\end{tabular}

$\mathrm{A}, \mathrm{B}, \mathrm{C}$ Means followed by different letters in the column for differentiating semen volume $(\mathrm{P}<0.05)$.

${ }^{\mathrm{A}, \mathrm{B}}$ Means followed by different letters in the column for differentiating spermatic vigor $(\mathrm{P}<0.05)$.

*Presence of gel in the third jet of one of the analyzed samples.

Table 2. Sperm concentration of the first three jets of sperm-rich fraction, regardless of jackass

\begin{tabular}{cc}
\hline Jet & $\mathrm{N}^{\mathrm{o}}$ cells $\left(\mathrm{x} 10^{6} \mathrm{sptz} / \mathrm{mL}\right)$ \\
\hline 1 & $955.56 \pm 64.15^{\mathrm{A}}$ \\
2 & $725.56 \pm 64.15^{\mathrm{B}}$ \\
3 & $280.56 \pm 64.15^{\mathrm{C}}$ \\
\hline
\end{tabular}

$\mathrm{A}, \mathrm{B}, \mathrm{C}$ Means followed by different letters on the column to differentiate them $(\mathrm{P}<0.05)$.
It was observed that, regardless of the jackass, the three jets had decreasing sperm concentration $(\mathrm{P}<0.05)$. Thus, a higher mean was observed for the first jet, followed by the second jet and the lowest concentration was in the third jet (Table 2). 
Table 3 shows that there was no jackass $\mathrm{x}$ jet interaction regarding the morphological characteristics of the first three jets. Data were grouped and comparisons were made between jets, regardless of the jackass (Table 4), and between jackasses, regardless of jet (Table 5).
Table 4 shows the percentage of normal sperm found on the first three jets collected. Differences $(\mathrm{P}<0.05)$ between jets were found only in the percentage of mid-piece defect, with higher occurrence in the third jet than in the first and second jets.

Table 3. Morphological characteristics of fresh semen from the first three jets of the sperm rich-fraction of Pêga jackasses

\begin{tabular}{ccccccccc}
\hline \multirow{2}{*}{ Jackass } & Jet & \multicolumn{7}{c}{ Sperm Morphology } \\
\cline { 3 - 8 } & & $\begin{array}{c}\text { Normal } \\
(\%)\end{array}$ & PCD $(\%)$ & DCD (\%) & MP (\%) & Tail $(\%)$ & Head (\%) & $\begin{array}{c}\text { Acrosome } \\
(\%)\end{array}$ \\
\hline \multirow{2}{*}{1} & 1 & $86.00 \pm 2.04$ & $2.50 \pm 1.56$ & $3.88 \pm 0.95$ & $2.75 \pm 0.57$ & $2.63 \pm 1.03$ & $2.00 \pm 0.44$ & $0.25 \pm 0.25$ \\
& 2 & $83.80 \pm 1.82$ & $3.00 \pm 1.40$ & $5.20 \pm 0.85$ & $3.50 \pm 0.51$ & $2.30 \pm 0.92$ & $1.80 \pm 0.40$ & $0.20 \pm 0.23$ \\
& 3 & $83.80 \pm 1.82$ & $1.80 \pm 1.40$ & $3.40 \pm 0.85$ & $4.40 \pm 0.51$ & $3.40 \pm 0.62$ & $2.30 \pm 0.40$ & $0.80 \pm 0.23$ \\
2 & 1 & $86.25 \pm 2.04$ & $3.63 \pm 1.56$ & $2.75 \pm 0.95$ & $3.00 \pm 0.57$ & $2.63 \pm 1.03$ & $1.75 \pm 0.44$ & $0.00 \pm 0.25$ \\
& 2 & $84.88 \pm 2.04$ & $4.38 \pm 1.56$ & $3.00 \pm 0.95$ & $3.00 \pm 0.57$ & $2.63 \pm 1.03$ & $1.75 \pm 0.44$ & $0.38 \pm 0.25$ \\
& 3 & $86.75 \pm 2.04$ & $2.63 \pm 0.95$ & $2.63 \pm 0.95$ & $2.38 \pm 0.57$ & $4.00 \pm 1.03$ & $1.00 \pm 0.44$ & $0.63 \pm 0.25$ \\
& 1 & $88.38 \pm 2.04$ & $1.13 \pm 1.56$ & $2.25 \pm 0.95$ & $2.38 \pm 0.57$ & $3.00 \pm 1.03$ & $2.38 \pm 0.44$ & $0.50 \pm 0.25$ \\
3 & 2 & $88.63 \pm 2.04$ & $1.25 \pm 1.56$ & $2.00 \pm 0.95$ & $2.88 \pm 0.57$ & $2.50 \pm 1.03$ & $2.38 \pm 0.44$ & $0.38 \pm 0.25$ \\
& 3 & $85.00 \pm 2.35$ & $0.50 \pm 1.81$ & $2.17 \pm 1.10$ & $4.50 \pm 0.65$ & $5.00 \pm 1.19$ & $2.50 \pm 0.51$ & $0.17 \pm 0.29$ \\
& 1 & $74.50 \pm 2.35$ & $7.67 \pm 1.81$ & $4.17 \pm 1.10$ & $7.67 \pm 0.65$ & $5.17 \pm 1.19$ & $0.50 \pm 0.51$ & $0.17 \pm 0.29$ \\
4 & 2 & $76.00 \pm 2.35$ & $7.67 \pm 1.81$ & $2.50 \pm 1.10$ & $6.67 \pm 0.65$ & $4.67 \pm 1.19$ & $2.17 \pm 0.51$ & $0.17 \pm 0.29$ \\
& 3 & $75.00 \pm 2.35$ & $9.17 \pm 1.81$ & $1.50 \pm 1.10$ & $8.00 \pm 0.65$ & $4.67 \pm 1.19$ & $1.33 \pm 0.51$ & $0.33 \pm 0.29$ \\
& 1 & $91.75 \pm 2.04$ & $1.63 \pm 1.56$ & $1.50 \pm 0.95$ & $1.00 \pm 0.57$ & $2.63 \pm 1.03$ & $1.50 \pm 0.44$ & $0.00 \pm 0.25$ \\
5 & 2 & $92.75 \pm 2.04$ & $1.63 \pm 1.56$ & $1.63 \pm 0.95$ & $0.88 \pm 0.57$ & $1.38 \pm 1.03$ & $1.63 \pm 0.44$ & $0.13 \pm 0.25$ \\
& 3 & $88.38 \pm 2.04$ & $1.63 \pm 1.56$ & $3.00 \pm 0.95$ & $2.00 \pm 0.57$ & $3.38 \pm 1.03$ & $1.38 \pm 0.44$ & $0.25 \pm 0.25$ \\
\hline
\end{tabular}

PCD - Proximal cytoplasmic droplet, DCD - Distal cytoplasmic droplet, MP- Mid-piece.

Table 4. Morphological characteristics of the first three jets of the sperm-rich fraction, regardless of jackass

\begin{tabular}{cccc}
\hline \multirow{2}{*}{ Sperm Morphology } & \multicolumn{3}{c}{ Jet } \\
\cline { 2 - 4 } & 1 & 2 & 3 \\
\hline Normal (\%) & $85.38 \pm 0.94$ & $85.21 \pm 0.92$ & $83.79 \pm 0.95$ \\
PCD (\%) & $3.31 \pm 0.72$ & $3.58 \pm 0.71$ & $3.14 \pm 0.73$ \\
DCD (\%) & $2.91 \pm 0.44$ & $2.87 \pm 0.43$ & $2.54 \pm 0.45$ \\
MP (\%) & $3.36 \pm 0.26^{\mathrm{b}}$ & $3.38 \pm 0.26^{\mathrm{b}}$ & $4.26 \pm 0.26^{\mathrm{a}}$ \\
Tail (\%) & $3.21 \pm 0.48$ & $2.69 \pm 0.47$ & $4.09 \pm 0.48$ \\
Head (\%) & $1.63 \pm 0.20$ & $1.94 \pm 0.20$ & $1.70 \pm 0.21$ \\
Acrosome (\%) & $0.18 \pm 0.12$ & $0.25 \pm 0.11$ & $0.44 \pm 0.12$ \\
\hline
\end{tabular}

${ }^{\mathrm{ab}}$ Means fallowed by different letters on the line to differentiate them $(\mathrm{P}<0.05)$.

PCD - Proximal cytoplasmic droplet, DCD - Distal cytoplasmic droplet, MP- Mid-piece.

However, when the morphological characteristics of the sperm-rich fraction of five jackasses were compared regardless of jet, differences were observed in the percentage of normal sperm, proximal cytoplasmic droplet, mid-piece and head defects. Jackass 5 had a higher $(\mathrm{P}<0.05)$ percentage of normal sperm than the others (Table 5). Higher $(\mathrm{P}<0.05)$ proximal cytoplasmic droplet and mid-piece defects were found in semen samples from jackass 4 when compared to the others. There was higher $(\mathrm{P}<0.05)$ incidence of head defect associated with jackass 3 when compared to jackass 4 . Jackasses 1, 2 and 5 had intermediate means that were similar to those found for jackasses 3 and 4 . The percentage of distal cytoplasmic droplet, tail and acrosome defects did not differ $(\mathrm{P}>0.05)$ between the five jackasses (Table 5). 
In general, after ejaculation of the first three jets that compose the sperm-rich fraction, elimination of gelatinous material, which is a characteristic of secretion from vesicular glands, was observed. The presence of this gel fraction in the third jet was observed in only one of the 18 ejaculates collected. Thus, while the ejaculate fraction of stallions can be composed of three to six jets
(Kosiniak, 1975), it was observed that the jackass sperm-rich fraction was composed of three jets in 17 out of 18 ejaculates collected, similarly to what was described by Mann et al. (1963). However, the rest of the ejaculate was not collected, precluding the determination of sperm concentration in the remaining jets.

Table 5. Morphological characteristics of the sperm-rich fraction from five Pêga jackasses, regardless of jet

\begin{tabular}{cccccc} 
Sperm & \multicolumn{5}{c}{ Jackass } \\
\cline { 2 - 6 } Morphology & 1 & 2 & 3 & 4 & 5 \\
\hline Normal (\%) & $84.53 \pm 1.10^{\mathrm{b}}$ & $85.96 \pm 1.18^{\mathrm{b}}$ & $87.33 \pm 1.24^{\mathrm{b}}$ & $75.17 \pm 1.36^{\mathrm{c}}$ & $90.96 \pm 1.18^{\mathrm{a}}$ \\
PCD (\%) & $2.43 \pm 0.84^{\mathrm{b}}$ & $3.54 \pm 0.90^{\mathrm{b}}$ & $0.96 \pm 0.95^{\mathrm{b}}$ & $8.17 \pm 1.04^{\mathrm{a}}$ & $1.63 \pm 0.90^{\mathrm{b}}$ \\
DCD (\%) & $4.16 \pm 0.51$ & $2.79 \pm 0.55$ & $2.14 \pm 0.58$ & $2.72 \pm 0.63$ & $2.04 \pm 0.55$ \\
MP (\%) & $3.55 \pm 0.30^{\mathrm{b}}$ & $2.79 \pm 0.33^{\mathrm{b}}$ & $3.25 \pm 0.34^{\mathrm{b}}$ & $7.44 \pm 0.38^{\mathrm{a}}$ & $1.29 \pm 0.33^{\mathrm{c}}$ \\
Tail (\%) & $2.78 \pm 0.55$ & $3.08 \pm 0.59$ & $3.50 \pm 0.63$ & $4.83 \pm 0.69$ & $2.46 \pm 0.59$ \\
Head (\%) & $2.03 \pm 0.24^{\mathrm{ab}}$ & $1.50 \pm 0.26^{\mathrm{ab}}$ & $2.42 \pm 0.27^{\mathrm{a}}$ & $1.33 \pm 0.30^{\mathrm{b}}$ & $1.50 \pm 0.26^{\mathrm{ab}}$ \\
Acrosome (\%) & $0.42 \pm 0.14$ & $0.33 \pm 0.15$ & $0.35 \pm 0.15$ & $0.22 \pm 0.17$ & $0.13 \pm 0.15$ \\
\hline
\end{tabular}

PCD - Proximal cytoplasmic droplet, DCD - Distal cytoplasmic droplet, MP- Mid-piece.

In an experiment conducted by Mann et al. (1963), the volumes of the first three jets that compose the sperm-rich fraction of jackass semen were 9, 17 and $9 \mathrm{~mL}$, respectively. These authors had higher volume values comparing with the results found on Table 1 of this experiment for jet 1 (2.55 to $13.75 \mathrm{~mL})$, jet 2 (1.15 to $14.50 \mathrm{~mL})$ and jet $3(3.80$ to $7.63 \mathrm{~mL})$. The use of only two jackasses in these study with no description of the number of ejaculates used should be emphasized. In addition, the different breeds of jackasses used for the present study and the Mann et al. (1963) study should be considered.

Sperm motility for the first three jets collected ranged from 62.50 to $87.50 \%$ (Table 1). There was a trend of reduced sperm motility between the first and third jet for all jackasses, although no statistical differences were identified. In general, the values observed are similar to those found in literature for the total semen ejaculate of jackasses (Ferreira, 1993; Morais et al., 1994; Crespo et al., 2003; Rossi, 2008; Canisso et al., 2010).

The sperm vigor for the first three jets evaluated ranged from 3.63 to 5.00 . It is worth mentioning that considering all jets from all jackasses, lower vigor $(3.63 \pm 0.29)$ in the third jet of jackass 1 was observed, in which the presence of gel in one of the four samples analyzed was identified.
Similarly to sperm motility, a trend of reduced vigor from the first to the third jet was observed, regardless of the jackass, although with no statistical differences between them.

Mann et al. (1963) reported decreasing sperm concentrations for portions that compose the sperm-rich fraction, and these ranged from more than $400 \times 10^{6} \mathrm{sptz} / \mathrm{mL}$ for the first jet to about $200 \times 10^{6} \mathrm{sptz} / \mathrm{mL}$ for the third jet, with intermediate sperm concentration in the second jet. It was observed that the sperm concentrations of the first and second jets from the present study (Table 2) were higher than those described by Mann et al. (1963). However, there was an inverse relationship between volume and sperm concentration, and the volumes obtained by these authors were higher than those obtained in this experiment (Table 1). In addition, variations in the physical characteristics of the semen can be attributed to breed differences.

It was also observed in this experiment that the sperm concentration in the first two jets was higher than those for authors that assessed all fractions of the collected semen, like Rossi (2008), who found values that ranged between 69.46 and $305.24 \times 10^{6} \mathrm{sptz} / \mathrm{mL}$, and Morais et al. (1994), $444.11 \pm 182.72 \times 10^{6} \mathrm{sptz} / \mathrm{mL}$. Thus, the high sperm concentrations observed in the first three jets of the sperm-rich fraction allowed adequate dilution rates when using this fraction 
of the ejaculate, minimizing the deleterious effects of seminal plasma during semen storage.

Regarding sperm morphology, the first three jets of the sperm-rich fraction had more than $83 \%$ of normal sperm (Table 4), in agreement with the literature on jackasses, where the percentage of abnormal forms is relatively low, approximately $16 \%$ in most reports (Kreuchauf, 1984, Henry et al., 1987; Costa et al., 1991; Morais et al., 1994; Gastal et al., 1997; Batista, 2003; Rossi, 2008). The exception was jackass 4 (Table 5), whose percentage of abnormal cells was approximately $25 \%$.

Sperm quality is an important factor that can alter reproductive performance. In this sense, Haag (1959) found higher pregnancy rates associated with stallions that had more than 50\% of motility and less than $40 \%$ of abnormal sperm cells. Later, Kenney et al. (1983) found that sperm concentration associated with normal sperm morphology and motility were the seminal characteristics that best explained variations in pregnancy rates obtained at the end of the breeding season. Similarly, Dowsett et al. (1984) and Jasko et al. (1990) have shown that motility and morphology were the most important factors for fertility results. On the other hand, Bielanski (1975) found that stallions with high levels of morphological abnormalities could have good fertility. Thus, the studies are controversial and none have correlated sperm morphology with fertility using jackass semen.

In conclusion, this study has shown that the first three jets of the sperm-rich fraction of Pêga jackasses were characterized by high-quality sperm. In general, motility, vigor and sperm morphology were similar when comparing jets, but volume and sperm concentration were different. The high sperm concentration $/ \mathrm{mL}$ of semen in jets 1 and 2 should be highlighted, which probably accounted for a high proportion of the total sperm ejaculated.

\section{ACKNOWLEDGEMENTS}

Laura Carvalho was sponsored by a postgraduate scholarship by FAPEMIG, Brazil. The authors thank Tarcísio Resende and Haras Lagoa Dourada Farm for the animals and farm unit used for this experiment.

\section{REFERENCES}

BATISTA, V.L. Comportamiento sexual y normalización de las características seminales del burro Catalán. 2003. 74f. Tesis (Master) - Instituto Agronomico Mediterrâneo de Zaragoza, Zaragoza, Spain.

BIELANSKI, W. The evaluation of stallion semen in aspects of fertility control and its use for artificial insemination. In: INTERNATIONAL SYMPOSIUM ON EQUINE REPRODUCTION, 1., 1974, Cambridge. Proceedings... Cambridge: [s.n.], 1975. p.19-24.

CANISSO, I.F.; CARVALHO, G.R.; DAVIES MOREL, M.C.G. et al. Sexual behavior and ejaculate characteristics in Pêga donkeys (Equus asinus) mounting estrous horse mares (Equus caballus). Theriogenology, v.73, p.56-63, 2010.

CARVER, D.A.; BALL, B.A. Lipase activity in stallion seminal plasma and effect of lipase on stallion spermatozoa during storage at $5^{\circ} \mathrm{C}$. Theriogenology, v.58, p.1587-1595, 2002.

COSTA, A.J.S.A.; VALE FILHO, V.R.; SOUTO, N.B. et al. Avaliação andrológica de jumentos (Equus asinus) da raça Pêga, em três regiões, duas em Minas Gerais e uma na Bahia. In: CONGRESSO BRASILEIRO DE REPRODUÇÃO ANIMAL, 9., 1991, Belo Horizonte. Anais... Belo Horizonte: Colégio Brasileiro de Reprodução Animal, 1991. p.449.

CRESPO, F.; ÁlVAREZ, A.L.; BENITO, D. et al. Caracterización de los parámetros seminales en el asno Zamorano-Leonés. In: CONGRESO IBÉRICO DE REPRODUCCIÓN ANIMAL, 4., 2003, Araucas. Proceedings... Araucas: [s.n.], 2003. p.84.

DOWSETT, K.F.; OSBORNE, H.G.; PATTIE, W.A. Morphological characteristics of stallion's spermatozoa. Theriogenology, v.22, p.463-472, 1984.

FERREIRA, M.F.L. Efeito de diluentes e taxa de resfriamento sobre a motilidade espermática $e$ fertilidade do sêmen de jumentos (Equus asinus). 1993. 67f. Dissertação (Mestrado em Medicina Veterinária) - Escola de Veterinária, Universidade Federal de Minas Gerais, Belo Horizonte, MG.

GASTAL, M.O.; HENRY, M.; BEKER, A.R. et al. Effect of ejaculation frequency and season on donkey jack semen. Theriogenology, v.47, p.627638, 1997. 
HAAG, F.M. Evaluation of "dismount" semen in thoroughbred horse breeding. J. Am. Vet. Med. Assoc., v.1, p.312-314, 1959.

HENRY, M.; OLIVEIRA, M.M.F.; DIAZ, A.P. et al. Comportamento de jumentos no período de cortejo e ato sexual. In: CONGRESSO BRASILEIRO DE REPRODUÇÃO ANIMAL, 7., 1987, Belo Horizonte. Anais... Belo Horizonte: Colégio Brasileiro de Reprodução Animal, 1987. p.71.

JASKO, D.J.; LEIN, D.H.; FOOTE, R.H. Determination of the relationship between sperm morphologic classifications and fertility in stallions: 66 cases (1987-1988). J. Am. Vet. Med. Assoc., v.197, p.389-394, 1990.

JASKO, D.J.; MORAN, D.M.; FARLIN, M.E. et al. Effect of seminal plasma dilution or removal on spermatozoal motion characteristics of cooled stallion semen. Theriogenology, v.35, p.1059-1067, 1991.

KENNEY, R.M.; HURTGEN, J.P.; PIERSON, R. et al. Society for theriogenology manual for clinical fertility evaluation of the stallion. Hastings: Society for Theriogenology, 1983. 100p.

KOSINIAK, K. Characteristics of the successive jets of ejaculated semen of stallions. J. Reprod. Fertil., Suppl.23, p.59-61, 1975.

KREUCHAUF, A. Reproductive physiology in the jackass. Anim. Res. Develop., v.20, p.51-78, 1984.

LOVE, C.C.; BRINSKO, S.P.; RIGBY, S.L. et al. Relationship of seminal plasma level and extender type to sperm motility and DNA integrity. Theriogenology, v.63, p.1584-1591. 2005.

MAGISTRINI, M.; LINDEBERG, H.; KOSKINEN, E. et al. Biophysical and $1^{\mathrm{H}}$ magnetic resonance spectroscopy characteristics of fractionated stallion ejaculates. J. Reprod. Fertil., Suppl.56, p.101-110, 2000.

MANN, T.; MINOTAKIS, C.S.; POLGE., C. Semen composition and metabolism in the stallion and jackass. J. Reprod. Fertil., v.5, p.109-122, 1963.
MELLO, S.L.V. Efeito da coleta fracionada de sêmen e de dois diluentes sobre a longevidade de espermatozoides de jumentos (Equus asinus) resfriados $a 5^{\circ} \mathrm{C}$. 1998. 97f. Dissertação (Mestrado em Medicina Veterinária) - Escola de Veterinária da Universidade Federal de Minas Gerais, Belo Horizonte, MG.

MIRÓ, J.; TABERNER, E.; RIVERA, M. et al. Effects of dilution and centrifugation on the survival of spermatozoa and the structure of motile sperm cell subpopulations in refrigerated Catalonian donkey semen. Theriogenology, v.72, p.1017-1022, 2009.

MOORE, A.I.; SQUIRES, E.L.; GRAHAM, J.K. Effect of seminal plasma on the cryopreservation of equine spermatozoa. Theriogenology, v.63, p.2372$2381,2005$.

MORAIS, R.N.; MUCCIOLO. R.G.; VIANA, W.G. Biologia reprodutiva de jumentos. III. $\mathrm{pH}$, osmolaridade e níveis de eletrólitos no sêmen. Braz. J. Vet. Res. Anim. Sci., v.31, p.145-151, 1994.

ROSSI, R. Comparação de dois diluidores na fertilidade de éguas inseminadas com sêmen asinino a fresco ou resfriado. 2008. 209f. Dissertação (Mestrado em Medicina Veterinária) Escola de Veterinária, Universidade Federal de Minas Gerais, Belo Horizonte, MG.

SAS. Statistical analysis system. Version 5. Cary: SAS Institute, 1999.

SERRES, C.; RODRÍGUEZ, A.; ALVAREZ, A.L. et al. Effect of centrifugation and temperature on the motility and plasma membrane integrity of Zamorano-leone's donkey semen. Theriogenology, v.58, p.329-332, 2002.

TISCHNER, M.; KOSINIAK, K.; BIELÁNSKI, W. Analysis of the pattern of ejaculation in stallion. $J$. Reprod. Fertil., v.41, p.329-335, 1974.

VARNER, D.D.; BLANCHARD, T.L.; LOVE, C.L. et al. Effects of semen fractionation and dilution ratio on equine spermatozoal motility parameters. Theriogenology, v.28, p.709-723, 1987. 